\title{
Effect of intramammary infection with non-aureus staphylococci in early lactation in dairy heifers on quarter somatic cell count and quarter milk yield during the first 4 months of lactation
}

\author{
D. Valckenier, ${ }^{1}$ S. Piepers, ${ }^{1}$ A. De Visscher, ${ }^{1}$ R. M. Bruckmaier,${ }^{2}$ and S. De Vliegher ${ }^{1 *}$ \\ ${ }^{1}$ M-team and Mastitis and Milk Quality Research Unit, Department of Reproduction, Obstetrics and Herd Health, Faculty of Veterinary Medicine, \\ Ghent University, Merelbeke, Belgium B-9820 \\ ${ }^{2}$ Veterinary Physiology, Vetsuisse Faculty, University of Bern, Bern, Switzerland $\mathrm{CH}-3001$
}

\section{ABSTRACT}

A longitudinal study was conducted to assess to what extent intramammary infection (IMI) with non-aureus staphylococci (NAS) within the first $4 \mathrm{~d}$ after calving in dairy heifers affects quarter milk yield (qMY) and quarter milk somatic cell count (qSCC) during the first 4 mo of lactation. In total, 324 quarters from 82 Holstein Friesian heifers from 3 commercial dairy herds equipped with an automatic milking system were included and followed from calving up to 4 mo in lactation. The automatic milking system allowed us to precisely determine the daily qMY. A milk sample from each quarter was collected in early lactation (between 1 and $4 \mathrm{~d}$ in milk) for bacteriological culturing and measurement of the qSCC. Subsequently, milk samples were taken on a biweekly basis for measurement of the qSCC. The milk prolactin level in early lactation was measured, and the relation with NAS IMI was determined. Overall, NAS IMI in early lactation caused only a slight but significant increase in qSCC compared with milk from noninfected quarters during the first 4 mo in lactation, whereas no significant difference in daily qMY was present between NAS-infected and noninfected quarters. The milk prolactin level in early lactation did not differ between NAS-infected and noninfected quarters either. Our data suggest that IMI with NAS (as a group) present shortly after calving do not have an adverse effect on later production. The milk prolactin concentrations were not dissimilar between NAS-infected and noninfected quarters and thus cannot explain why NAS-infected quarters do not produce less than noninfected quarters.

Key words: non-aureus staphylococci, quarter milk yield, quarter somatic cell count, prolactin

Received October 29, 2018.

Accepted February 27, 2019.

*Corresponding author: Sarne.Devliegher@UGent.be

\section{INTRODUCTION}

A large proportion of heifers freshen with IMI and prevalence varies widely, with 12.3 to $74.6 \%$ of quarters being infected (reviewed by De Vliegher et al., 2012). A common denominator in all studies reporting on IMI in early-lactating dairy heifers is the large proportion of infections caused by NAS. Previous studies have shown a percentage of NAS-positive mammary quarters at first calving of up to $45.5 \%$ (Oliver et al., 2003).

Non-aureus staphylococci are a heterogeneous group consisting of more than 50 species and subspecies (Vanderhaeghen et al., 2015). Thus far, more than 10 species of NAS have been isolated from bovine milk (Supré et al., 2011; Vanderhaeghen et al., 2014; De Visscher et al., 2016). However, the effect of IMI caused by NAS on milk yield (MY) remains inconclusive. Some studies have classified NAS as an important cause of bovine mastitis with potentially negative effects on MY (Timms and Schultz, 1987; Gröhn et al., 2004; Taponen et al., 2006), whereas others consider them to be minor mastitis pathogens that only slightly increase milk SCC but do not affect MY (Paradis et al., 2010; Pearson et al., 2013; Tomazi et al., 2015). A more recent study concluded that the negative effect of NAS, identified using PCR, on udder health and MY should not be underestimated (Heikkilä et al., 2018). Some studies, however, observed higher test-day MY in NAS-infected dairy heifers and multiparous cows compared with noninfected herd mates (Schukken et al., 2009; Piepers et al., 2013). Still, in all but 1 study (i.e., Tomazi et al., 2015), both SCC and MY were measured at the animal level, making it difficult to relate the differences in testday milk SCC and MY between animals to the infection status of a specific quarter or quarters infected with a specific mastitis pathogen or pathogens in (early) lactation. A drawback of the study of Tomazi et al. (2015) is that the quarter MY (qMY) was determined only at a single milking. To unequivocally determine the association between NAS IMI in early lactation and milk 
SCC and MY further in lactation, a longitudinal study is needed in which the IMI status as well as the SCC and MY are measured (repeatedly) at the quarter level.

One of the hypotheses to explain the higher MY in NAS-infected heifers compared with noninfected herd mates is that NAS IMI might enhance the local production of prolactin (PRL) in the mammary gland. Prolactin is a hormone involved in a broad range of biological processes and is crucial for the initiation and maintenance of lactation in ruminants (Lacasse et al., 2016). Milk production significantly decreases when dairy cows receive long-term treatment with the selective dopamine receptor agonist quinagolide (Lacasse et al., 2011). In general, serum PRL lies between 10 and $60 \mathrm{ng} / \mathrm{mL}$ in adult dairy cows (Koprowski et al., 1972; Fulkerson et al., 1980; Marcek and Swanson, 1984). Prolactin is transported from the bloodstream to the milk across mammary epithelial cells via the transcytosis pathway. After binding on the membrane receptor on these cells, PRL is internalized; carried throughout endosomes, multivesicular bodies, and the Golgi apparatus; and subsequently released into the milk through secretory vesicles (Ollivier-Bousquet, 1998). The milk PRL concentration is overall lower than the circulating PRL level (Malven and McMurtry, 1974). The mammary gland can function as a self-regulating endocrine organ that is largely independent from systemic influences (Wilde and Peaker, 1990; Weaver and Hernandez, 2016). Nevertheless, the biological significance of autocrine PRL, and its potential correlation with milk secretion, has not been studied extensively in cattle. Damage to the mammary tissue due to mastitis increases the tight junction permeability, thereby enabling the paracellular transport of blood-borne components (Nguyen and Neville, 1998), which might result in the leaking of PRL from the bloodstream into the milk. Previous studies could not find a difference in blood PRL level between healthy cows, cows with clinical mastitis (CM), and cows with subclinical mastitis (SCM; Hockett et al., 2000; Boutet et al., 2007). On the contrary, the SCC of chronically infected quarters was found to be positively correlated with milk PRL concentration (Boutet et al., 2007). More recently, the average milk PRL level tended to be higher in NAS-infected quarters than in noninfected quarters in an experimental infection trial (Piccart et al., 2015). Piccart (2016) confirmed that, like in other ruminants such as sheep and goats (Le Provost et al., 1994), the bovine mammary gland is able to synthesize PRL, but PRL gene expression was not higher in NAS-challenged mammary epithelial cells compared with unchallenged control cells. On the other hand, the general correlation between mRNA and the final protein can be low, and the MAC-T cells that were used to study PRL gene expression might not be a reliable reflection of the complete dairy cow udder.

The main objective of this study was to unravel to what extent IMI with NAS in quarters from dairy heifers in early lactation truly affect qMY and quarter milk SCC (qSCC) during the first 4 mo of lactation. A longitudinal study on 3 dairy herds equipped with an automatic milking system (AMS) was conducted, allowing us to measure daily MY at the quarter level. The second objective was to scrutinize the association between early-lactation NAS IMI and quarter milk PRL concentration.

\section{MATERIALS AND METHODS}

\section{Sample Size}

Prior to the study, a sample size calculation was performed using SPSS SamplePower 3.0 (IBM, Armonk, NY) for clustered data. Assuming that 35\% of the quarters were infected with NAS and that $50 \%$ of the quarters were noninfected between 1 and 4 DIM (Piepers et al., 2010), an $\alpha$ of 0.05, an intraclass correlation coefficient of 0.5 at the quarter level, and a standard deviation of $1.5 \mathrm{~kg}, 72$ heifers were needed to detect a difference in milk production of $0.4 \mathrm{~kg}$ between NAS-infected and noninfected quarters using a linear mixed regression model taking the clustering of the 10 observations within quarters into account with a power of $80 \%$. The intraclass correlation coefficient and standard deviation were derived from a data set obtained from the Ghent University dairy farm (BiocentrumAgrivet, Melle, Belgium) equipped with an AMS. As clustering of quarters within heifers was not taken into account, the sample size calculation was probably slightly underestimated. Therefore, and to compensate for nonfunctional quarters at calving, contaminated milk samples, and heifers getting culled before the end of the study, the number of heifers included in the study was increased to 82 .

\section{Herds, Animals, and Study Design}

The study was conducted between the end of August 2013 and the end of October 2014. Eighty-two Holstein Friesian dairy heifers were included from 3 commercial dairy herds in the province of West Flanders (Belgium) equipped with an AMS. Herd owners were approached by the first author and asked whether they were willing to participate. None of the 3 herds treated their endterm heifers with antimicrobials before calving. None of the herds participated in the local dairy herd improvement program. 
In all herds, cows were milked automatically. Herds 1 and 3 had 2 AMS each, whereas there was only 1 AMS in herd 2. In herd 1 and 3, the lactating cows were housed in a separate group per AMS. The average number of lactating cows during the study period was 128, 60, and 115 in herds 1, 2, and 3, respectively. All cows were black and white Holstein Friesians. The average daily milk production per cow was $29.9,28.8$, and $27.5 \mathrm{~kg}$ in herds 1,2 , and 3 , respectively. The average number of milkings per cow per day in the 3 herds during the study period varied between 1.93 and 2.11.

In all 3 herds, all lactating cows and heifers were housed in freestall barns with a concrete slatted floor and cubicles bedded with sawdust. The cubicles were cleaned, and fresh bedding was added at least once a day. In all herds, the slatted floors were automatically cleaned at least twice per day with a robotic scraper. Hairs from the udders were clipped at least 2 times per year.

Heifers with signs of impending calving were separated in a calving pen on straw. In herd 1, those heifers were kept separated from cows close to calving and sick or injured animals, which were housed in 2 different (calving) pens. In herds 2 and 3, cows and heifers close to calving were kept together and housed in the same pen as the sick animals.

The first author visited the herds 2 times per week, on Monday and Thursday, to perform quarter milk sampling of the heifers that had calved since the previous visit. Every heifer was thus sampled between 1 and $4 \mathrm{~d}$ after calving. After the first sampling, all heifers were followed up until 127 to 130 DIM.

During the trial period, every heifer that calved was included in the study. No further inclusion or exclusion criteria at the herd or heifer levels were applied. When a heifer was sold, was culled, or died within the first 4 mo of lactation, it was not replaced by another animal. Nonfunctional quarters or quarters with CM before or at the first sampling were excluded because the main objective of this study was to investigate the effect of NAS IMI causing SCM on qSCC and qMY. For this reason, 2 quarters with $\mathrm{CM}$ and 2 nonfunctional quarters were excluded from the final data set.

Advice with respect to mastitis prevention and control was not given to the farmers or their herd veterinarians before or during the trial period. In addition, the culture results and SCC data were not made available to avoid alterations in the udder health management or antimicrobial treatment based on these data.

\section{Sampling and Data Recording}

One milk sample was taken within 1 to $4 \mathrm{~d}$ after calving (referred to as early lactation throughout the article) from each quarter of the heifers. All samples were taken aseptically according to the guidelines of the National Mastitis Council (Hogan et al., 1999). Briefly, gross contamination was removed from the teat skin and teat end with a dry paper towel. Subsequently, all teats were forestripped (3-5 streams), and the milk was inspected for visual abnormalities and discarded. The teat end and the bottom third of the teat were scrubbed with a cotton gauze or paper cloth moistened with ethanol (96\%; VWR International BVBA, Leuven, Belgium). When needed, more than 1 gauze was used per teat. Approximately 6 to $8 \mathrm{~mL}$ of milk was collected per sample in sterile vials. Postsampling, teats were dipped with a chlorite-based dipping solution (Uddergold Platinum, Ecolab Europe GmbH, Wallisellen, Switzerland). All samples were transported in a cooled box $\left(4^{\circ} \mathrm{C}\right)$ to the laboratory of the Mastitis and Milk Quality Research Unit (Ghent University, Merelbeke, Belgium) for bacteriological culturing and determination of qSCC. Quarter milk production per milking was available through the herd management software of the AMS (DelPro, DeLaval International AB, Tumba, Sweden).

Farmers were asked to record all CM cases that occurred during the first 4 mo after calving in one of the included heifers and to aseptically collect milk samples (approximately 6-8 $\mathrm{mL}$ ) of every $\mathrm{CM}$ case (visible abnormalities in the udder or milk, such as presence of flakes or a swollen or painful quarter). Those milk samples were stored at $-18^{\circ} \mathrm{C}$ until the next herd visit and then collected by the first author for further processing.

\section{Microbiology}

Standard culturing of all milk samples was performed according to the guidelines of the National Mastitis Council (Hogan et al., 1999). Briefly, a 0.01-mL loop of milk was spread on both an esculin blood agar plate and a MacConkey agar plate (Thermo Fisher Diagnostics N.V., Groot-Bijgaarden, Belgium) and aerobically incubated at $37^{\circ} \mathrm{C}$. The plates were phenotypically examined after $24 \mathrm{~h}$ and again after $48 \mathrm{~h}$. Quarters were considered to be infected if 1 or more colonies were observed $(\geq 100 \mathrm{cfu} / \mathrm{mL})$ in the milk sample. Identification of bacteria was done by Gram staining, inspection of the colony morphology, and biochemical testing. Catalase tests were performed to differentiate gram-positive cocci as catalase-positive or catalase-negative cocci. Staphylococci (gram-positive, catalase-positive cocci) were identified as Staphylococcus aureus or NAS by colony morphology, coagulase testing, hemolysis patterns, and DNase tests. Isolates of the Streptococcus-Enterococcus group were differ- 
entiated as esculin-positive or esculin-negative cocci. Christie, Atkins, and Munch-Petersen tests were used to differentiate esculin-negative cocci as Streptococcus agalactiae or Streptococcus dysgalactiae. Gram-negative bacteria were differentiated in oxidase-negative and oxidase-positive bacteria and further identified using the EnteroPluri-Test (Liofilchem, Roseto degli Abruzzi, Italy) or Oxi/FermPluri-Test (Liofilchem) identification systems, respectively, and classified as Escherichia coli, Klebsiella spp., or other gram-negative bacteria.

Non-aureus staphylococci and Corynebacterium spp. were considered to be minor pathogens. Staphylococcus aureus, esculin-positive and esculin-negative cocci, Trueperella pyogenes, E. coli, Klebsiella spp., and other gram-negative bacteria were regarded as major pathogens. A quarter yielding a major and a minor pathogen was classified as infected with the major pathogen, whereas a quarter yielding 2 major or 2 minor pathogens was considered to be infected with the bacteria with the highest colony-forming units per milliliter. Samples yielding 3 or more bacterial species were considered to be contaminated. After a loop of milk was spread on the agar plates and the qSCC was determined, $1 \mathrm{~mL}$ of each sample was stored at $-20^{\circ} \mathrm{C}$ in Eppendorf cups for determination of the PRL concentration.

\section{CM and Culling}

One quarter was immediately dried-off after CM between 85 and 102 DIM, but no milk sample was collected by the herd owner. The left hind quarter from a heifer in herd 3 was dried-off at 85 DIM because of a teat end injury. The samples taken before these quarters were dried-off were included in the analysis.

Two heifers from herd 3 were culled after a severe case of CM between 57 and 74 DIM. Streptococcus dysgalactiae was identified as the causative pathogen in the former quarter, whereas no bacteria could be cultured from the milk sample in the latter case. Two heifers (herds 2 and 3) were sold between 85 and 102 DIM. The samples taken before these 4 animals were culled were included in the analysis.

\section{Quarter-Level IMI}

From the 82 heifers included in this study, 324 quarters were eligible for sampling in early lactation (i.e., 1-4 DIM). Of these 324 quarters, the qIMI status could not be defined for 15 quarters because the milk samples were considered to be contaminated, and these quarters were excluded from the entire study. A quarter was defined as having an IMI with NAS, Bacillus spp., Corynebacterium spp., Staph. aureus, Streptococcus spp., T. pyogenes, or gram-negative bacteria at calving when the sample collected between 1 and 4 DIM contained $\geq 100 \mathrm{cfu} / \mathrm{mL}$ of the specific bacteria (Dohoo et al., 2011). A total of 220 quarters were noninfected in early lactation, whereas 89 quarters were infected with any pathogen (Table 1). The majority of the infected quarters at this sampling were infected with NAS $(\mathrm{n}=68$; $76.4 \%$ of infected quarters). Major pathogens (Staph. aureus, esculin-positive cocci, and E. coli) accounted for only $10.1 \%$ of the infected quarters. Six quarters were infected with Corynebacterium spp. and 6 were infected

Table 1. Overview of the bacteriological culturing results from samples collected in early lactation (1-4 DIM) and the associated quarter milk SCC (qSCC) at first (1-4 DIM) and second (15-18 DIM) sampling days in 324 quarters from 82 dairy heifers

\begin{tabular}{|c|c|c|c|c|c|c|c|c|c|}
\hline \multirow[b]{3}{*}{ Item } & \multirow[b]{3}{*}{$\begin{array}{c}\text { No. of } \\
\text { quarters }\end{array}$} & \multirow{3}{*}{$\begin{array}{c}\% \text { of } \\
\text { quarters } \\
(\mathrm{n}=324)\end{array}$} & \multirow{3}{*}{$\begin{array}{c}\% \text { of } \\
\text { positive } \\
\text { samples } \\
(\mathrm{n}=89)\end{array}$} & \multicolumn{6}{|c|}{ qSCC $(\times 1,000$ cells $/ \mathrm{mL})$} \\
\hline & & & & \multicolumn{3}{|c|}{ First sampling day } & \multicolumn{3}{|c|}{ Second sampling day } \\
\hline & & & & $\begin{array}{c}\text { Geometric } \\
\text { mean }\end{array}$ & Minimum & Maximum & $\begin{array}{c}\text { Geometric } \\
\text { mean }\end{array}$ & Minimum & Maximum \\
\hline Culture negative $^{1}$ & 220 & 67.9 & - & 353 & 13 & 5,078 & 64 & 1 & 4,620 \\
\hline \multicolumn{10}{|l|}{ Culture positive } \\
\hline Corynebacterium spp. & 6 & 1.85 & 6.74 & 116 & 2 & 678 & 40 & 8 & 511 \\
\hline Bacillus spp. & 6 & 1.85 & 6.74 & 784 & 162 & 4,463 & 63 & 8 & 1,004 \\
\hline Staphylococcus aureus ${ }^{2}$ & 2 & 0.62 & 2.25 & 1,190 & 535 & 2,648 & 716 & 601 & 853 \\
\hline 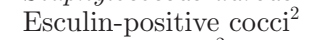 & 2 & 0.62 & 2.25 & 1,531 & 495 & 4,738 & 438 & 71 & 2,705 \\
\hline Escherichia coli ${ }^{2}$ & 5 & 1.54 & 5.62 & 210 & 92 & 1,174 & 178 & 25 & 4,046 \\
\hline $\mathrm{NAS}^{3}$ & 68 & 20.99 & 76.4 & 394 & 11 & 5,037 & 96 & 7 & 3,587 \\
\hline Contaminated $^{4}$ & 15 & 4.63 & - & 244 & 56 & 1,313 & 96 & 16 & 1,505 \\
\hline
\end{tabular}


with Bacillus spp. Only quarters that were noninfected $(\mathrm{n}=220)$ or infected with either NAS $(\mathrm{n}=68)$ or a major pathogen $(\mathrm{n}=9)$ in early lactation were retained for further analyses.

\section{Quarter SCC}

After the early-lactation sampling (within 1-4 DIM), quarter milk samples were collected every $14 \mathrm{~d}$ for 9 consecutive times (10 so-called sampling days in total). The qSCC of each sample was measured using a DeLaval Cell Counter DCC (DeLaval International AB, Tumba, Sweden) in the laboratory of the Mastitis and Milk Quality Research group at the Faculty of Veterinary Medicine of Ghent University (Merelbeke, Belgium).

\section{$q M Y$}

The qMY in early lactation (1-4 DIM) was calculated by summing the quarter MY per milking per day from calving up to $\mathrm{d} 7$ after sampling divided by the number of days. Subsequently, the qMY was also followed for 9 consecutive 14-d periods (sampling days) by calculating the average daily qMY during each of these periods.

\section{Milk PRL Concentration}

All frozen $\left(-20^{\circ} \mathrm{C}\right)$ quarter milk samples collected in early lactation (1-4 DIM; $\mathrm{n}=325)$ were thawed to $20^{\circ} \mathrm{C}$ and centrifuged $(25 \mathrm{~min}$ at $3,000 \times g)$. The lower lipid-depleted aqueous phase was used to determine milk PRL by RIA as previously described by Bruckmaier et al. (1992).

\section{Statistical Analyses}

All data were entered in an electronic spreadsheet program (Excel 2010, Microsoft Corp., Redmond, WA) and were checked for unlikely values.

Quarter Milk SCC and $M Y$. The association between quarter IMI (qIMI) status in early lactation (determined between 1 and 4 DIM; predictor variable of main interest) and the sampling-day qSCC and sampling-day qMY (outcome variables) throughout the first $4 \mathrm{mo}$ of lactation, respectively, was determined fitting 2 separate linear mixed models (PROC MIXED) in SAS (version 9.4; SAS Institute Inc., Cary, NC). A natural logarithmic transformation of SCC (LnSCC) was performed to obtain a normal distribution. All models included DIM (between 1 and 130 DIM) and its quadratic term as continuous predictor variables. The 3 qIMI status levels (noninfected, infected with NAS, and infected with 1 or more major pathogens) was forced in all models as a categorical predictor variable of main interest. Quarter position (2 levels: front vs. hind) was added to the models as a categorical predictor variable. Additionally, the model for sampling day qMY was fit with quarter LnSCC (qLnSCC) at sampling day as a continuous predictor variable. Herd was forced into all models as a fixed effect to correct for potential clustering of heifers within herds. Heifer and quarter were added as random effects to account for clustering of quarters within heifer and clustering of observation (10 repeated samplings, including the one in early lactation) within quarters, respectively. In all linear mixed models, a first-order autoregressive correlation structure was used to account for the clustering of repeated sampling days within a quarter.

The initial linear mixed model with qSCC as outcome variable was

$$
\begin{aligned}
\operatorname{LnSCC}_{\mathrm{ijkl}}= & \beta_{0}+\beta_{1} \mathrm{qIMI}_{\mathrm{jkl}}+\beta_{2} \text { Quarter position }_{\mathrm{jkl}} \\
+\beta_{3} \operatorname{Herd}_{\mathrm{kl}} & +\beta_{4} \mathrm{DIM}_{\mathrm{ijkl}}+\beta_{5} \mathrm{DIM}_{\mathrm{ijkl}}^{2}+\mu_{\text {Heifer kl(j) }} \\
& +\mu_{\text {Quarter jkl(i) }}+\mathrm{e}_{\mathrm{ijkl}},
\end{aligned}
$$

where $\operatorname{LnSCC}_{\mathrm{ijkl}}$ is the natural logarithm of SCC for the ith sample $(\mathrm{i}=1-10)$ of the jth quarter $(\mathrm{j}=1-4)$ of the kth heifer $(\mathrm{k}=1-82)$ from the lth herd $(1=1-3) ; \beta_{0}$ is the intercept (overall mean); $\beta_{1}$ to $\beta_{5}$ are the regression coefficients of the fixed effects (IMI status in early lactation, quarter position, herd, DIM, and DIM quadratic, respectively); $\mu_{\text {Heifer } \mathrm{kl}(\mathrm{j})}$ is the random effect of heifer $\mathrm{k}$ from herd $\mathrm{l}$ to correct for clustering of quarters within heifer; $\mu_{Q \text { uarter jkl(i) }}$ is the random effect to correct for within-quarter correlation of subsequent biweekly sampling days $\mathrm{i}$ (repeated statement) for quarter $\mathrm{j}$ of heifer $\mathrm{k}$ from herd $\mathrm{l}$; and $\mathrm{e}_{\mathrm{ijkl}}$ is the random error term.

The initial model with outcome variable daily qMY was

$$
\begin{aligned}
& \mathrm{qMY}_{\mathrm{ijkl}}=\beta_{0}+\beta_{1} \mathrm{qIMI}_{\mathrm{jkl}}+\beta_{2} \text { Quarter position }_{\mathrm{jkl}} \\
& +\beta_{3} \operatorname{Herd}_{\mathrm{kl}}+\beta_{4} \mathrm{DIM}_{\mathrm{ijkl}}+\beta_{5} \mathrm{DIM}_{\mathrm{ijkl}}^{2}+\beta_{6} \operatorname{LnSCC}_{\mathrm{ijkl}} \\
& +\mu_{\text {Heifer kl(j) }}+\mu_{\text {Quarter jkl(i) }}+\mathrm{e}_{\mathrm{ijkl}},
\end{aligned}
$$

where $\mathrm{qMY}_{\mathrm{ijkl}}$ is the $\mathrm{qMY}$ for the ith sample $(\mathrm{i}=1-10)$ of the jth quarter $(\mathrm{j}=1-4)$ of the kth heifer $(\mathrm{k}=$ $1-82)$ from the lth herd $(1=1-3) ; \beta_{0}$ is the intercept (overall mean); $\beta_{1}$ to $\beta_{6}$ are the regression coefficients of the fixed effects (IMI status in early lactation, quarter position, herd, DIM, DIM quadratic, and the natural logarithm of the qSCC, respectively); $\mu_{\text {Heifer } \mathrm{kl}(\mathrm{j})}$ is the random effect of heifer $\mathrm{k}$ from herd $\mathrm{l}$ to correct for clustering of quarters within heifer; $\mu_{\text {Quarter jkl(i) }}$ is the random effect to correct for within-quarter correlation of subsequent biweekly sampling days i (repeated state- 
ment) for quarter $\mathrm{j}$ of heifer $\mathrm{k}$ from herd $\mathrm{l}$; and $\mathrm{e}_{\mathrm{ijkl}}$ is the random error term.

Quarter Milk PRL. The association between the qIMI status (predictor variable of main interest) and the quarter milk PRL (qPRL) concentration (outcome variable; $\mathrm{ng} / \mathrm{mL}$ ) in early lactation (determined between 1 and 4 DIM) was studied using a linear mixed model (PROC MIXED) in SAS (version 9.4; SAS Institute Inc., Cary, NC). The model was fit with season of calving (4 levels: January-March, April-June, July-September, October-December) and quarter position (2 levels: front vs. hind) as categorical predictor variables. The variable $\mathrm{DIM}_{\text {early }}$ (4 levels: 1 DIM, 2 DIM, 3 DIM, 4 DIM) was included in the model as a categorical predictor variable to correct for the expected rapid decrease of the milk PRL concentration within the first days after calving (Koprowski et al., 1972; Edgerton and Hafs, 1973; Marcek and Swanson, 1984). Daily qMY in early lactation was included in the model as a continuous predictor variable. The qIMI status (3 levels: noninfected, infected with NAS, and infected with 1 or more major pathogens) was forced in the model as a categorical predictor variable of main interest. Herd was forced into the model as a fixed effect to correct for potential clustering of heifers within herds. Heifer was added as a random effect to account for clustering of quarters within heifer.

The initial linear mixed model with PRL as an outcome variable was

$$
\begin{gathered}
\text { PRL }_{\mathrm{jkl}}=\beta_{0}+\beta_{1} \mathrm{qIMI}_{\mathrm{jkl}}+\beta_{2} \text { Quarter position }_{\mathrm{jkl}} \\
+\beta_{3} \operatorname{Herd}_{\mathrm{kl}}+\beta_{4} \mathrm{DIM}_{\text {early kl }}+\beta_{5} \text { Season }_{\mathrm{kl}}+\beta_{6} \mathrm{qMY}_{\mathrm{jkl}} \\
+\mu_{\text {Heifer kl }(\mathrm{j})}+\mathrm{e}_{\mathrm{jk} l},
\end{gathered}
$$

where $\mathrm{PRL}_{\mathrm{jkl}}$ is the predicted milk PRL concentration of the jth quarter $(\mathrm{j}=1-4)$ of the kth heifer $(\mathrm{k}=1-82)$ from the lth herd $(1=1-3) ; \beta_{0}$ is the intercept (overall mean); $\beta_{1}$ to $\beta_{6}$ are the regression coefficients of the fixed effects (IMI status in early lactation, quarter position, herd, DIM at the sampling day in early lactation, season of calving, and qMY, respectively); $\mu_{\mathrm{Heifer} \mathrm{kl}(\mathrm{j})}$ is the random effect of heifer $\mathrm{k}$ from herd $\mathrm{l}$ to correct for clustering of quarters within heifer; and $\mathrm{e}_{\mathrm{jkl}}$ is the random error term.

For all linear mixed models, the goodness-of-fit measures included $-2 \times \log$-likelihood, the Akaike information criterion, and the Bayesian information criterion. Residuals were evaluated graphically and plotted against the predicted values. A Bonferroni's correction was used to correct for multiple comparisons. Significance was assessed at $P \leq 0.05$. Nonsignificant variables $(P>0.05)$ were omitted using a backward stepwise approach.
Likelihood of NAS IMI. The association between the likelihood of NAS IMI (noninfected vs. NAS infected; outcome variable) and quarter position (front vs. hind; predictor variable) at the first sampling was studied using a logistic mixed regression model (PROC GLIMMIX) in SAS (version 9.4; SAS Institute Inc., Cary, NC). Herd was forced into the model as a fixed effect to correct for potential clustering of heifers within herds. Heifer was added as a random effect to account for clustering of quarters within heifer. Significance was assessed at $P \leq 0.05$. The odds ratio and $95 \%$ confidence interval were calculated. The logistic mixed model used for NAS IMI was

$$
\begin{aligned}
\operatorname{logit}\left(\mathrm{p}_{\mathrm{jkl}}\right)=\beta_{0} & +\beta_{1} \text { Quarter } \operatorname{position}_{\mathrm{jkl}}+\beta_{2} \operatorname{Herd}_{\mathrm{kl}} \\
& +\mu_{\text {Heifer kl }(\mathrm{j})}+\mathrm{e}_{\mathrm{jk} l},
\end{aligned}
$$

where $\operatorname{logit}\left(\mathrm{p}_{\mathrm{jkl}}\right)=\ln \left[\mathrm{p}_{\mathrm{jkl}} /\left(1-\mathrm{p}_{\mathrm{jkl}}\right)\right]$, and $\mathrm{p}_{\mathrm{jkl}}=$ $\mathrm{P}\left(\mathrm{qIMI}_{\mathrm{NAS}} \mathrm{jkl}\right)$ denotes the probability of quarter $\mathrm{j}$ from heifer $\mathrm{k}$ in herd $\mathrm{l}$ having an NAS IMI; qIMI $\mathrm{NAS}_{\mathrm{k} k \mathrm{l}}$ is a binary qIMI status observation (noninfected vs. NAS infected) of the jth quarter $(\mathrm{j}=1-4)$ of the kth heifer $(\mathrm{k}=1-82)$ from the lth herd $(1=1-3)$. Furthermore, $\beta_{0}$ is the intercept (overall mean); $\beta_{1}$ and $\beta_{2}$ are the regression coefficients of the fixed effects (quarter position and herd, respectively); $\mu_{\text {Heifer kl(j) }}$ is the random effect of heifer $\mathrm{k}$ from herd $\mathrm{l}$ to correct for clustering of quarters within heifer; and $\mathrm{e}_{\mathrm{jkl}}$ is the random error term.

\section{RESULTS}

\section{Likelihood of NAS IMI}

With almost $21 \%$ of quarters eligible for sampling in early lactation (1-4 DIM) being infected with NAS (Table 1), this group of pathogens had the highest prevalence in our study. The likelihood of having an IMI with NAS in early lactation in a hind quarter was $76 \%$ higher compared with a front quarter (odds ratio $=1.76 ; 95 \% \mathrm{CI}=0.98-3.16 ; P=0.06)$.

\section{Effect of Quarter-Level IMI on qSCC}

The geometric mean qSCC in milk from noninfected quarters at the first (1-4 DIM; early lactation) and second (15-18 DIM) sampling days was 353,000 and 64,000 cells $/ \mathrm{mL}$, respectively (Table 1 ). Milk from NAS-infected quarters had a slightly higher geometric mean qSCC (394,000 and 96,000 cells/mL at the first and second sampling days, respectively), whereas the geometric mean qSCC in milk from quarters infected with a major pathogen was 480,000 and 285,000 cells/ $\mathrm{mL}$ at the first and second sampling days, respectively. The evolution of the qSCC over the first 4 mo of lacta- 
Table 2. Final linear mixed regression model describing the association between the natural log-transformed quarter milk SCC (outcome variable) during the first 4 mo of lactation and quarter-level IMI (qIMI) status in early lactation (1-4 DIM; main predictor of interest) of 297 quarters from 82 dairy heifers in 3 herds

\begin{tabular}{|c|c|c|c|c|c|}
\hline Predictor variable & $\begin{array}{c}\text { No. of } \\
\text { quarters }\end{array}$ & Estimate & $\mathrm{SE}$ & $P$-value & LSM \\
\hline Intercept & - & 5.36 & 0.11 & $<0.001$ & - \\
\hline Herd $^{1}$ & & & & 0.20 & \\
\hline Herd 1 & 148 & Referent & - & - & 4.46 \\
\hline Herd 2 & 60 & 0.005 & 0.15 & 0.97 & 4.47 \\
\hline Herd 3 & 89 & 0.23 & 0.14 & 0.09 & 4.69 \\
\hline DIM & - & -0.05 & 0.002 & $<0.001$ & - \\
\hline $\mathrm{DIM} \times \mathrm{DIM}$ & - & 0.0003 & 0.00002 & $<0.001$ & - \\
\hline qIMI in early lactation & & & & $<0.001$ & \\
\hline Noninfected & 220 & Referent & - & - & 4.19 \\
\hline Infected with NAS & 68 & 0.30 & 0.08 & $<0.001$ & 4.49 \\
\hline Infected with $\mathrm{MP}^{2}$ & 9 & 0.75 & 0.22 & $<0.001$ & 4.94 \\
\hline
\end{tabular}

${ }^{1}$ Herd was forced in the model to correct for potential clustering of heifers within herds.

${ }^{2}$ Major pathogen.

tion in milk from noninfected quarters and quarters infected with NAS or a major pathogen in early lactation is depicted in Figure 1.

The variable quarter position was not significant and was omitted from the final model. Milk from quarters infected with NAS had a significantly higher samplingday $\mathrm{qLnSCC}$ than noninfected quarters $(\mathrm{LSM}=4.49$ and 4.19, respectively; $P<0.001$; Table 2 ) and a not statistically significant lower sampling-day $\mathrm{qLnSCC}$ than milk from quarters infected with a major pathogen $(\mathrm{LSM}=4.94 ; P=0.14)$.

\section{Effect of Quarter-Level IMI on qMY}

The average daily MY of a noninfected quarter at the first sampling day (1-4 DIM; early lactation) was 4.62 $\mathrm{kg}$ (Table 3). The evolution of the daily qMY at sampling day as a function of the qIMI statuses is depicted in Figure 1. The daily MY over the first $4 \mathrm{mo}$ of the first lactation did not differ between quarters infected with NAS $(7.39 \mathrm{~kg} / \mathrm{d})$ and noninfected quarters (7.35 $\mathrm{kg} / \mathrm{d} ; \mathrm{SE}=0.19 ; P=0.99)$. Excluding quarter position from the model as a predictor variable resulted in

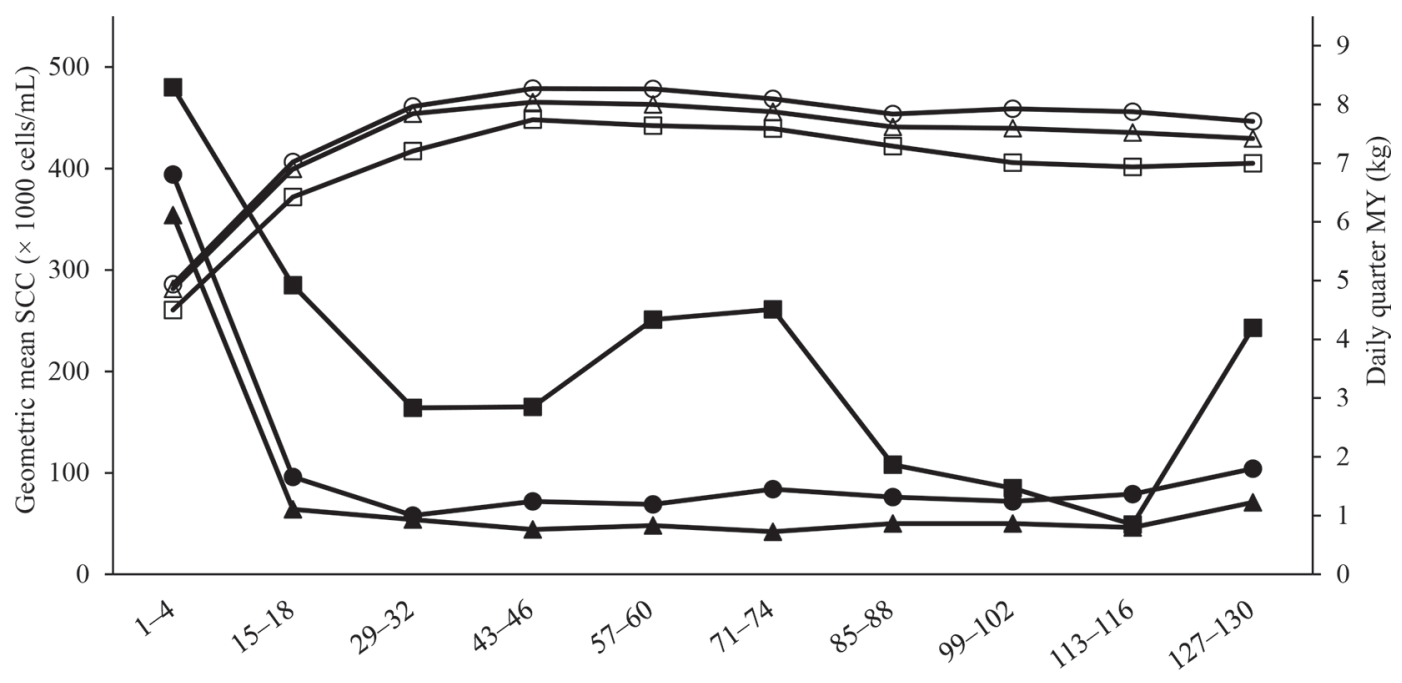

Days in milk

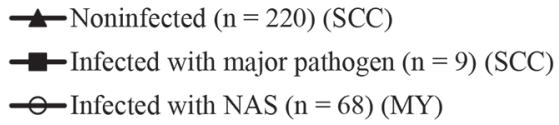

$$
\begin{aligned}
& \text {-Infected with NAS }(n=68)(\mathrm{SCC}) \\
& \square \text { Noninfected }(\mathrm{n}=220)(\mathrm{MY}) \\
& \square \text { Infected with major pathogen }(\mathrm{n}=9)(\mathrm{MY})
\end{aligned}
$$

Figure 1. Evolution of average quarter daily milk yield (MY) and geometric mean quarter milk SCC during the first 4 mo of lactation in quarters that were noninfected, infected with NAS, or infected with a major pathogen in early lactation (1-4 DIM). 
Table 3. Final linear mixed regression model describing the association between quarter milk yield (outcome variable) during the first 4 mo of lactation and quarter-level IMI (qIMI) status in early lactation (1-4 DIM; main predictor of interest) of 297 quarters from 82 dairy heifers in 3 herds

\begin{tabular}{|c|c|c|c|c|c|c|c|c|c|}
\hline \multirow[b]{2}{*}{ Predictor variable } & \multirow{2}{*}{$\begin{array}{c}\text { No. of } \\
\text { quarters }\end{array}$} & \multicolumn{4}{|c|}{ Full model } & \multicolumn{4}{|c|}{ Model without quarter position } \\
\hline & & Estimate & $\mathrm{SE}$ & $P$-value & LSM & Estimate & $\mathrm{SE}$ & $P$-value & LSM \\
\hline Herd $^{1}$ & & & & 0.13 & & & & 0.16 & \\
\hline Herd 1 & 148 & Referent & - & - & 7.11 & Referent & - & - & 7.02 \\
\hline Herd 2 & 60 & -0.16 & 0.29 & 0.58 & 6.95 & -0.10 & 0.30 & 0.73 & 6.92 \\
\hline Herd 3 & 89 & 0.43 & 0.26 & 0.10 & 7.54 & 0.44 & 0.26 & 0.10 & 7.46 \\
\hline qIMI in early lactation & & & & 0.56 & & & & 0.19 & \\
\hline Noninfected & 220 & Referent & - & - & 7.35 & Referent & - & - & 7.32 \\
\hline Infected with NAS & 68 & 0.04 & 0.19 & 0.83 & 7.39 & 0.19 & 0.20 & 0.33 & 7.51 \\
\hline Infected with $\mathrm{MP}^{2}$ & 9 & -0.51 & 0.50 & 0.31 & 6.84 & -0.75 & 0.52 & 0.16 & 6.57 \\
\hline Quarter position & & & & $<0.001$ & & & & - & \\
\hline Front & 152 & Referent & - & - & 6.73 & - & - & - & - \\
\hline Hind & 145 & 0.92 & 0.14 & $<0.001$ & 7.66 & - & - & - & - \\
\hline
\end{tabular}

${ }^{1}$ Herd was forced in the model to correct for potential clustering of heifers within herds.

${ }^{2}$ Major pathogen.

${ }^{3}$ Natural log-transformed quarter milk SCC.

larger estimates $(0.19 \mathrm{~kg} / \mathrm{d} ; \mathrm{SE}=0.20 ; P=0.33)$. Hind quarters produced on average $0.93 \mathrm{~kg}$ more per day compared with front quarters $(P<0.001)$. Noninfected quarters produced $0.51 \mathrm{~kg}$ more per day during the remainder of the first lactation compared with quarters infected with a major pathogen in early lactation (SE $=0.51 ; P=0.92)$. Excluding quarter position as a predictor variable from the model increased this difference to $0.75 \mathrm{~kg} / \mathrm{d}(\mathrm{SE}=0.52 ; P=0.16$; Table 3$)$.

\section{PRL}

The average $\mathrm{qPRL}$ concentration in milk in early lactation (1-4 DIM) was $100.43 \mathrm{ng} / \mathrm{mL}$, with a strong decrease of the qPRL concentration over time. Samples that were collected at 1 DIM had an average qPRL concentration of $144.71 \mathrm{ng} / \mathrm{mL}$, whereas at 2 DIM the concentration was $91.69 \mathrm{ng} / \mathrm{mL}$. The lowest levels were reached at 3 and 4 DIM, with 51.52 and $58.43 \mathrm{ng} / \mathrm{mL}$, respectively. The qPRL concentration in early lactation as a function of the IMI status (noninfected quarters vs. quarters infected with NAS) is depicted in Figure 2.

The variable season was not significant and was omitted from the final model. The average qPRL concentration did not differ significantly between the 3 herds $(P=0.52$; Table 4$)$. Also, the qIMI status and season of calving were not significantly associated with qPRL concentration ( $P=0.98$ and 0.16 , respectively). Still, quarter position had an influence on qPRL concentration. The PRL concentration in milk collected from a hind quarter was $7.71 \mathrm{ng} / \mathrm{mL}$ higher $(P<0.001)$ than that in milk collected from a front quarter. The daily
qMY was negatively associated with the qPRL concentration (estimate $=-2.93 ; \mathrm{SE}=1.01 ; P=0.004$ ).

\section{DISCUSSION}

This is the first longitudinal study that investigated the effect of IMI status of quarters of early-lactating heifers, and more specifically the presence of NAS, on the qMY and qSCC throughout lactation in 3 herds equipped with an AMS. The latter approach allowed for matching the qIMI status in early lactation to the qMY and qSCC during the first 4 mo of lactation. By doing so, the major drawback of previous studies in which MY was measured at the animal level rather than per quarter and where the IMI status of the heifers was an aggregate of the quarter-level IMI statuses was elegantly circumvented. With $21 \%$ of the 324 quarters enrolled in this study being NAS infected, this group of pathogens was clearly the most prevalent cause of IMI in the early-lactation heifers, as expected (De Vliegher et al., 2012).

Quarters were considered to have an IMI if $\geq 100 \mathrm{cfu} /$ $\mathrm{mL}$ was cultured (definition A in Dohoo et al., 2011). The goal of the authors was to identify as many existing infections as possible and to reduce the chances of an infected quarter being misclassified as noninfected. We opted for the threshold with the highest sensitivity and thus the lowest percentage of false-negative results because the main goal of our study was to compare the effect of IMI with NAS on the qSCC and qMY against noninfected quarters or quarters infected with a major pathogen. The higher SCC in milk from quarters 


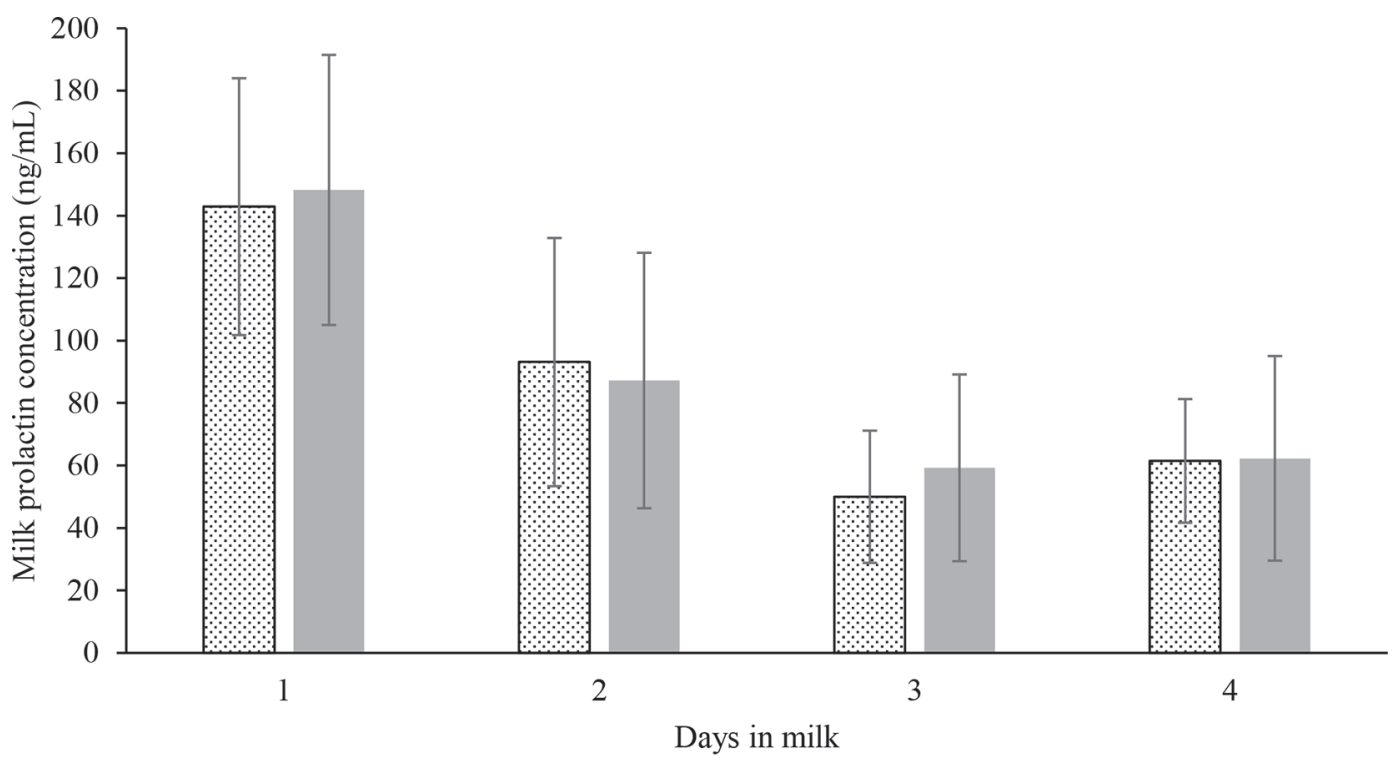

$\square$ Noninfected quarters $(\mathrm{n}=220) \quad \square$ Quarters infected with NAS $(\mathrm{n}=68)$

Figure 2. Evolution of the quarter milk prolactin concentration of quarters sampled in early lactation (1-4 DIM) as a function of IMI status (noninfected vs. infected with NAS). Error bar $= \pm 1$ SD.

considered to be infected with NAS using the threshold of $100 \mathrm{cfu} / \mathrm{mL}$ compared with noninfected quarters indicated that quarters that were culture-positive for NAS were truly infected with NAS. Also, a huge and overlapping variation was seen in the number of colonyforming units per milliliter between the $25 \%$ lowest producing quarters and the $25 \%$ highest producing quarters (minimum $=100$, maximum $=1,600$; data not shown), indicating that the effect of NAS infections on qMY did not depend on the number of isolated colonies from the milk sample.

The increase in SCC in milk as a result of the inflammatory response due to an infection of the quarter with NAS was less pronounced than the response to

Table 4. Final linear mixed regression model describing the association between quarter milk prolactin concentration $(\mathrm{ng} / \mathrm{mL}$ ) (outcome variable) and quarter IMI (qIMI) status (main predictor of interest) in early lactation (1-4 DIM) of 297 quarters from 82 dairy heifers in 3 herds

\begin{tabular}{|c|c|c|c|c|c|}
\hline Predictor variable & $\begin{array}{l}\text { No. of } \\
\text { quarters }\end{array}$ & Estimate & $\mathrm{SE}$ & $P$-value & LSM \\
\hline Intercept & - & 154.37 & 7.83 & $<0.001$ & - \\
\hline Herd $^{1}$ & & & & 0.52 & \\
\hline Herd 1 & 148 & Referent & - & - & 87.33 \\
\hline Herd 2 & 60 & 8.05 & 10.12 & 0.43 & 95.38 \\
\hline Herd 3 & 89 & -4.36 & 8.71 & 0.62 & 82.96 \\
\hline DIM in early lactation & - & & & $<0.001$ & - \\
\hline $1 \mathrm{DIM}$ & 124 & Referent & - & - & 145.57 \\
\hline 2 DIM & 70 & -51.03 & 9.61 & $<0.001$ & 94.54 \\
\hline 3 DIM & 80 & -92.84 & 9.45 & $<0.001$ & 52.72 \\
\hline 4 DIM & 23 & -84.18 & 14.99 & $<0.001$ & 61.39 \\
\hline qIMI status at calving & & & & 0.98 & \\
\hline Noninfected & 220 & Referent & - & - & 88.19 \\
\hline Infected with NAS & 68 & 0.27 & 2.01 & 0.89 & 89.02 \\
\hline Infected with $\mathrm{MP}^{2}$ & 9 & 0.84 & 5.86 & 0.89 & 88.45 \\
\hline Quarter position & & & & $<0.001$ & \\
\hline Front & 152 & Referent & - & - & 84.70 \\
\hline Hind & 145 & 7.71 & 1.32 & $<0.001$ & 92.41 \\
\hline $\mathrm{qMY}^{3}$ at sampling day & - & -2.93 & 1.01 & 0.004 & - \\
\hline
\end{tabular}

${ }^{1}$ Herd was forced in the model to correct for potential clustering of heifers within herds.

${ }^{2}$ Major pathogen.

${ }^{3}$ Quarter daily milk yield (kg). 
IMI caused by major pathogens, which is in line with previous findings (Piepers et al., 2010; Supré et al., 2011). The overall geometric mean qSCC steeply decreased between the first and second sampling day, as was expected based on the findings of previous studies in which either composite (Dohoo, 1993; Laevens et al., 1997; Piepers et al., 2010) or quarter (Barkema et al., 1999; De Visscher et al., 2016) milk samples were collected. In the study of Barkema et al. (1999), the geometric mean qSCC in milk from noninfected quarters was as low as 42,000 cells $/ \mathrm{mL}$ at the sixth milking after calving versus 170,000 cells $/ \mathrm{mL}$ in milk from NAS-infected quarters and 1,257,000 cells/mL in milk from quarters infected with a major pathogen. Still, the effect of NAS on the qSCC in general (Piccart et al., 2016) and after parturition in particular might differ among the different NAS species (De Visscher et al., 2016).

Despite the higher qSCC, quarters infected with NAS in early lactation did not produce less milk than noninfected quarters. Numerically, NAS-infected quarters even outproduced noninfected quarters, whereas quarters infected with major pathogens produced less milk than noninfected quarters. This is in accordance with previous findings showing that heifers infected with NAS in early lactation produced $2 \mathrm{~kg}$ of milk/d more than heifers that were not infected in early lactation (Piepers et al., 2013). The discrepancy between both studies in terms of significance might be partially explained by a lack of power (17\% rather than $80 \%$; data not shown) in our study because the assumptions made for the sample size calculation did not completely fit with the data obtained in our study. The difference in MY between NAS-infected and noninfected quarters was much lower than what was expected based on Piepers et al. (2010; $0.5 \mathrm{~kg} / \mathrm{d})$. Also, the standard deviation of the data in the present study was larger compared with the test data set (1.82 and 1.50, respectively), and the proportion of NAS-infected quarters in the present study was lower compared with the prevalence obtained in the study of Piepers et al. (2010; 21 and $33 \%$, respectively), resulting in a lower total number of NAS-infected quarters than estimated in the sample size calculation. The lack of power in our study might also partially explain why the numerically lower daily MY in quarters infected with a major pathogen was not significantly different from the MY of noninfected quarters. Actually, only 9 quarters were infected with a major pathogen in early lactation. Moreover, more than half of these infections were caused by $E$. coli, which contrasts with the study of Piepers et al. (2010). In the latter study, Staph. aureus was the causative pathogen in $37 \%$ of the major pathogen-infected quarters. The higher prevalence of Staph. aureus might also explain the higher milk losses at the heifer level in that study because according to Heikkilä et al. (2018), SCM with Staph. aureus can lead to average milk losses of $2.2 \mathrm{~kg} / \mathrm{d}$ until 305 DIM, whereas mastitis caused by E. coli had an effect only on the 305-d MY in the case of CM.

Hind quarters outproduced the front quarters by $0.93 \mathrm{~kg} / \mathrm{d}$, as expected, yet interestingly the likelihood of having an NAS IMI in a hind quarter tended to be 1.76 higher $(P=0.06)$ compared with a front quarter. Correcting the model with $\mathrm{qMY}$ as an outcome variable for the quarter position effect by adding this potential confounder as a categorical variable to the model further decreased the average difference in qMY between NAS-infected and noninfected quarters from 0.19 to $0.04 \mathrm{~kg} / \mathrm{d}$. In the studies by De Visscher et al. (2015, 2016), however, no significant difference in the distribution of NAS infections between front and hind quarters was found in general, although hind quarters tended $(P=0.087)$ to be more infected with the less relevant NAS species (De Visscher et al., 2015). Still, one should take into account that, by dividing the NAS species into a more and a less relevant group, the number of quarters per group was relatively small and that in these data sets both heifers and multiparous cows were considered. The different infection dynamics during the dry period (e.g., IMI that were already present at dry-off and that did not cure during the dry period) and the use of long-acting antimicrobials at drying-off in the multiparous cows only might have influenced the prevalence of NAS infections within the first days after calving as well. Also, in another study, the likelihood of NAS IMI in early-lactating heifers was not affected by quarter position (Piepers et al., 2011), leaving us with the question of whether the finding in our study that hind quarters are more prone to NAS IMI is a coincidence. High-yielding multiparous dairy cows might inherently be more prone to NAS infections, but this effect was not found in heifers (Gröhn et al., 2004). In the latter study, multiparous cows with clinical NAS mastitis produced significantly more milk (between 2.3 and $2.7 \mathrm{~kg} / \mathrm{d}$ ) 1 mo before diagnosis than their noninfected herd mates. According to Piepers et al. (2013), the association between MY and NAS IMI was only partially confounded by the genetic potential for milk production, as including the breeding index for MY did not fully explain the observed difference in MY. These findings are reinforced by our data. Out of the 82 heifers included in our study, 28 heifers were culture-negative in all functional quarters at the first sampling day. Also, excluding these heifers from the data set had little to no effect on the association between NAS IMI and the sample day qMY and qSCC (data not shown). 
Remarkably, the higher qSCC in milk from NASinfected quarters compared with noninfected quarters had little effect on the qMY estimates for NAS-infected quarters. One of the potential explanations for this somewhat awkward finding is that the increase in qSCC could have been mainly due to an increase in epithelial cells or macrophages and lymphocytes instead of neutrophils, which generally cause the greatest damage to the udder tissue (Capuco et al., 1986; Paape et al., 2002). Differential cell counting would probably have given more insight into the distribution of the different cell populations. Still, at the onset of this study, no routine method for differential cell counting (Damm et al., 2017) was available as it is now.

A possible explanation for the finding that IMI with NAS did at least not have a negative effect on qMY could be found in the effect of NAS IMI on the PRL levels. Recent studies (Lacasse et al., 2011; Lacasse and Ollier, 2015; Lacasse et al., 2016) have shown the importance of PRL measured in circulating plasma as a galactopoietic hormone in cattle. In our study, however, no difference could be found in the qPRL concentration between noninfected and NAS-infected quarters. This might support our finding that the qMY between noninfected and NAS-infected quarters did not significantly differ. The higher milk PRL levels in hind quarters, having the highest daily qMY, compared with front quarters supports the positive correlation between PRL level and MY. Results from a trial in which heifers in mid lactation were experimentally infected with 3 strains of NAS showed a slightly higher milk PRL level in infected quarters, although the difference with the control quarters was not significant (Piccart et al., 2015). Future studies should further unravel the local production of PRL in the (infected) bovine mammary gland and its role in the inflammatory pathways (e.g., neutrophil activation and migration) in bovine mastitis.

\section{CONCLUSIONS}

Non-aureus staphylococci (as a group) were the most prevalent mastitis pathogens, accounting for $76.4 \%$ of the IMI in early-lactating heifers. Our data support the status of NAS as a group as minor pathogens, only slightly elevating the qSCC in milk from infected quarters compared with noninfected quarters. No significant difference in the daily qMY could be found between NAS-infected and noninfected quarters. The odds of the hind quarters being NAS infected were $76 \%$ higher compared with front quarters, explaining at least partly why NAS-infected quarters had a numerically slightly higher qMY compared with noninfected quarters in this study. The milk PRL level in early lactation did not differ between NAS-infected and noninfected quarters.
To further scrutinize the ability of (certain) NAS species to cause persistent IMI and the effect of transient versus persistent infections in freshly calved heifers on qMY and qSCC during the remainder of the lactation, further identification to the species level of the isolated NAS is needed.

\section{ACKNOWLEDGMENTS}

The farmers who cooperated in this work are gratefully acknowledged. The authors thank Yolande Zbinden (Veterinary Physiology, University of Bern, Switzerland) for measurement of the prolactin concentration in the milk samples. None of the authors have a financial or personal relationship with other people or organizations that could inappropriately influence or bias the content of the paper.

\section{REFERENCES}

Barkema, H. W., H. A. Deluyker, Y. H. Schukken, and T. J. Lam. 1999. Quarter-milk somatic cell count at calving and at the first six milkings after calving. Prev. Vet. Med. 38:1-9.

Boutet, P., J. Sulon, R. Closset, J. Detilleux, J. F. Beckers, F. Bureau, and P. Lekeux. 2007. Prolactin-induced activation of nuclear factor kappaB in bovine mammary epithelial cells: Role in chronic mastitis. J. Dairy Sci. 90:155-164.

Bruckmaier, R. M., D. Schams, and J. W. Blum. 1992. Aetiology of disturbed milk ejection in parturient primiparous cows. J. Dairy Res. 59:479-489.

Capuco, A. V., M. J. Paape, and S. C. Nickerson. 1986. In vitro study of polymorphonuclear leukocyte damage to mammary tissues of lactating cows. Am. J. Vet. Res. 47:663-668.

Damm, M., C. Holm, M. Blaabjerg, M. N. Bro, and D. Schwarz. 2017. Differential somatic cell count-A novel method for routine mastitis screening in the frame of Dairy Herd Improvement testing programs. J. Dairy Sci. 100:4926-4940.

De Visscher, A., S. Piepers, F. Haesebrouck, and S. De Vliegher. 2016. Intramammary infection with coagulase-negative staphylococci at parturition: Species-specific prevalence, risk factors, and effect on udder health. J. Dairy Sci. 99:6457-6469.

De Visscher, A.. S. Piepers, K. Supré, F. Haesebrouck, and S. De Vliegher. 2015. Short communication: Species group-specific predictors at the cow and quarter level for intramammary infection with coagulase-negative staphylococci in dairy cattle throughout lactation. J. Dairy Sci. 98:5448-5453.

De Vliegher, S., L. K. Fox, S. Piepers, S. McDougall, and H. W. Barkema. 2012. Invited review: Mastitis in dairy heifers: Nature of the disease, potential impact, prevention, and control. J. Dairy Sci. 95:1025-1040

Dohoo, I. R. 1993. An evaluation of the validity of individual cow somatic cell counts from cows in early lactation. Prev. Vet. Med. $16: 103-110$

Dohoo, I. R., J. Smith, S. Andersen, D. F. Kelton, S. Godden, and Mastitis Research Workers' Conference. 2011. Diagnosing intramammary infections: Evaluation of definitions based on a single milk sample. J. Dairy Sci. 94:250-261.

Edgerton, L. A., and H. D. Hafs. 1973. Serum luteinizing hormone, prolactin, glucocorticoid, and progestin in dairy cows from calving to gestation. J. Dairy Sci. 56:451-458.

Fulkerson, W. J., G. J. Sawyer, and C. B. Gow. 1980. Investigations of ultradian and circadian-rhythms in the concentration of cortisol and prolactin in the plasma of dairy cattle. Aust. J. Biol. Sci. $33: 557-561$ 
Gröhn, Y. T., D. J. Wilson, R. N. Gonzalez, J. A. Hertl, H. Schulte, G. Bennett, and Y. H. Schukken. 2004. Effect of pathogen-specific clinical mastitis on milk yield in dairy cows. J. Dairy Sci. $87: 3358-3374$.

Heikkilä, A. M., E. Liski, S. Pyörälä, and S. Taponen. 2018. Pathogen-specific production losses in bovine mastitis. J. Dairy Sci. 101:9493-9504.

Hockett, M. E., F. M. Hopkins, M. J. Lewis, A. M. Saxton, H. H. Dowlen, S. P. Oliver, and F. N. Schrick. 2000. Endocrine profiles of dairy cows following experimentally induced clinical mastitis during early lactation. Anim. Reprod. Sci. 58:241-251.

Hogan, J. S., R. N. Gonzales, R. J. Harmon, S. C. Nickerson, S. P. Oliver, J. W. Pankey, and K. L. Smith. 1999. Laboratory Handbook on Bovine Mastitis. Rev. ed. National Mastitis Council, Madison, WI.

Koprowski, J. A., H. A. Tucker, and E. M. Convey. 1972. Prolactin and growth hormone circadian periodicity in lactating cows. Proc. Soc. Exp. Biol. Med. 140:1012-1014.

Lacasse, P., V. Lollivier, R. M. Bruckmaier, Y. R. Boisclair, G. F. Wagner, and M. Boutinaud. 2011. Effect of the prolactin-release inhibitor quinagolide on lactating dairy cows. J. Dairy Sci. 94:1302-1309.

Lacasse, P., and S. Ollier. 2015. The dopamine antagonist domperidone increases prolactin concentration and enhances milk production in dairy cows. J. Dairy Sci. 98:7856-7864.

Lacasse, P., S. Ollier, V. Lollivier, and M. Boutinaud. 2016. New insights into the importance of prolactin in dairy ruminants. J. Dairy Sci. 99:864-874.

Laevens, H., H. Deluyker, Y. H. Schukken, L. De Meulemeester, R Vandermeersch, E. De Muelenaere, and A. De Kruif. 1997. Influence of parity and stage of lactation on the somatic cell count in bacteriologically negative dairy cows. J. Dairy Sci. 80:3219-3226.

Le Provost, F., C. Leroux, P. Martin, P. Gaye, and J. Dijane. 1994. Prolactin gene expression in ovine and caprine mammary gland. Neuroendocrinology 60:305-313.

Malven, P. V., and J. McMurtry. 1974. Measurement of prolactin in milk by radioimmunoassay. J. Dairy Sci. 57:411-415.

Marcek, J. M., and L. V. Swanson. 1984. Effect of photoperiod on milk production and prolactin of Holstein dairy cows. J. Dairy Sci. 67:2380-2388.

Nguyen, D. A.,, and M. C. Neville. 1998. Tight junction regulation in the mammary gland. J. Mammary Gland Biol. Neoplasia 3:233246.

Oliver, S. P., M. J. Lewis, B. E. Gillespie, H. H. Dowlen, E. C. Jaenicke, and R. K. Roberts. 2003. Prepartum antibiotic treatment of heifers: Milk production, milk quality and economic benefit. J. Dairy Sci. 86:1187-1193.

Ollivier-Bousquet, M. 1998. Transferrin and prolactin transcytosis in the lactating mammary epithelial cell. J. Mammary Gland Biol. Neoplasia 3:303-313.

Paape, M., J. Mehrzad, X. Zhao, J. Detilleux, and C. Burvenich. 2002. Defense of the bovine mammary gland by polymorphonuclear neutrophil leukocytes. J. Mammary Gland Biol. Neoplasia 7:109-121.

Paradis, M. E., E. Bouchard, D. T. Scholl, F. Miglior, and J. P. Roy. 2010. Effect of nonclinical Staphylococcus aureus or coagulase-negative staphylococci intramammary infection during the first month of lactation on somatic cell count and milk yield in heifers. J. Dairy Sci. 93:2989-2997.

Pearson, L. J., J. H. Williamson, S. A. Turner, S. J. Lacy-Hulbert, and J. E. Hillerton. 2013. Peripartum infection with Streptococcus uberis but not coagulase-negative staphylococci reduced milk production in primiparous cows. J. Dairy Sci. 96:158-164.

Piccart, K. 2016. The host-pathogen interaction of ecologically diverse coagulase-negative staphylococci in bovine mastitis, with a focus on prolactin. $\mathrm{PhD}$ thesis. Ghent University, Ghent, Belgium.

Piccart, K., S. Piepers, J. Verbeke, N. M. de Sousa, J. F. Beckers, and S. De Vliegher. 2015. Milk prolactin response and quarter milk yield after experimental infection with coagulase-negative staphylococci in dairy heifers. J. Dairy Sci. 98:4593-4600.

Piccart, K., J. Verbeke, A. De Visscher, S. Piepers, F. Haesebrouck, and S. De Vliegher. 2016. Local host response following an intramammary challenge with Staphylococcus fleurettii and different strains of Staphylococcus chromogenes in dairy heifers. Vet. Res. 47:56.

Piepers, S., G. Opsomer, H. W. Barkema, A. de Kruif, and S. De Vliegher. 2010. Heifers infected with coagulase-negative staphylococci in early lactation have fewer cases of clinical mastitis and higher milk production in their first lactation than noninfected heifers. J. Dairy Sci. 93:2014-2024.

Piepers, S., K. Peeters, G. Opsomer, H. W. Barkema, K. Frankena, and S. De Vliegher. 2011. Pathogen group specific risk factors at herd, heifer and quarter levels for intramammary infections in early lactating dairy heifers. Prev. Vet. Med. 99:91-101.

Piepers, S., Y. H. Schukken, P. Passchyn, and S. De Vliegher. 2013. The effect of intramammary infection with coagulase-negative staphylococci in early lactating heifers on milk yield throughout first lactation revisited. J. Dairy Sci. 96:5095-5105.

Schukken, Y. H., R. N. Gonzalez, L. L. Tikofsky, H. F. Schulte, C. G. Santisteban, F. L. Welcome, G. J. Bennett, M. J. Zurakowski, and R. N. Zadoks. 2009. CNS mastitis: Nothing to worry about? Vet. Microbiol. 134:9-14.

Supré, K., F. Haesebrouck, R. N. Zadoks, M. Vaneechoutte, S. Piepers, and S. De Vliegher. 2011. Some coagulase-negative Staphylococcus species affect udder health more than others. J. Dairy Sci. 94:2329-2340.

Taponen, S., H. Simojoki, M. Haveri, H. D. Larsen, and S. Pyörälä. 2006. Clinical characteristics and persistence of bovine mastitis caused by different species of coagulase-negative staphylococci identified with API or AFLP. Vet. Microbiol. 115:199-207.

Timms, L. L., and L. H. Schultz. 1987. Dynamics and significance of coagulase-negative staphylococcal intramammary infections. J. Dairy Sci. 70:2648-2657.

Tomazi, T., J. L. Goncalves, J. R. Barreiro, M. A. Arcari, and M. V. dos Santos. 2015. Bovine subclinical intramammary infection caused by coagulase-negative staphylococci increases somatic cell count but has no effect on milk yield or composition. J. Dairy Sci. 98:3071-3078.

Vanderhaeghen, W., S. Piepers, F. Leroy, E. Van Coillie, F. Haesebrouck, and S. De Vliegher. 2014. Invited review: Effect, persistence, and virulence of coagulase-negative Staphylococcus species associated with ruminant udder health. J. Dairy Sci. 97:5275-5293.

Vanderhaeghen, W.. S. Piepers, F. Leroy, E. Van Coillie, F. Haesebrouck, and S. De Vliegher. 2015. Identification, typing, ecology and epidemiology of coagulase negative staphylococci associated with ruminants. Vet. J. 203:44-51.

Weaver, S. R., and L. L. Hernandez. 2016. Autocrine-paracrine regulation of the mammary gland. J. Dairy Sci. 99:842-853.

Wilde, C. J., and M. Peaker. 1990. Autocrine control in milk secretion. J. Agric. Sci. 114:235-238. 